\title{
HUBUNGAN ANTARA MOTIVASI KERJA DENGAN KINERJA PEGAWAI DI FAKULTAS TARBIYAH DAN KEGURUAN UNIVERSITAS ISLAM NEGERI ALAUDDIN MAKASSAR
}

\author{
SUARGA DAN NURITA \\ Fakultas Tarbiyah dan Keguruan UIN Alauddin Makassar \\ JI. HM. Yasin Limpo No. 36 Makassar \\ Email: suargabk@gmail.com
}

\begin{abstract}
:
This study discusses motivation of employee, the performance of employees, and the relationship between work motivation with employee performance in the Faculty of Tarbiyah UIN Alauddin Makassar. The purpose of this study; Firstly, to know the motivation of employee work in Faculty of Tarbiyah and Teacher Training UIN Alauddin Makassar, Secondly, to know the performance of employees in Faculty of Tarbiyah and Teacher Training UIN Alauddin Makassar and Thirdly, to know the significant relationship between work motivation with employee performance in Faculty of Tarbiyah and Teacher Training UIN Alauddin Makassar. This research was quantitative research associative by educational and psychological approach. Population in this research was all employees both civil servants and honorary in Faculty of Tarbiyah and Teacher Training UIN Alauddin Makassar, which amounted to 43 people or using total sampling. The instrument used in this study was a Likert scale questionnaire about work motivation and employee performance. Data analysis techniques used are descriptive statistical analysis and inferential statistical analysis. The results of research shows that employee motivation in the Faculty of Tarbiyah and Teacher Training UIN Alauddin Makassar is in the medium category, which is equal to $67 \%$. The performance of employees at the Faculty of Tarbiyah and Teacher Training UIN Alauddin Makassar also is in the medium category, which is equal to $65 \%$. Therefore, this study indicate that there is a significant relationship between work motivation and employee performance of $0.997 \%$. Hence the relationship between these two variables is very strong.
\end{abstract}

Keywords: Work Motivaton; employees performance

\section{PENDAHULUAN}

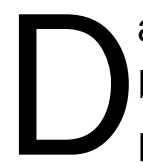

alam era globalisasi saat ini, ditandai dengan adanya perubahan yang begitu cepat, suatu lembaga dituntut untuk mengadakan penyesuaianpenyesuaian dalam semua segi yang ada pada lembaga tersebut. Dengan terbatasnya sumber daya manusia yang ada, lembaga diharapkan dapat mengoptimalkannya sehingga tercapai tujuan organisasi yang telah ditetapkan. Sumber daya manusia merupakan bagian dari dalam suatu kemajuan ilmu, pembangunan, dan teknologi. Untuk itu sumber daya manusia memerlukan pendidikan.

Karena pendidikan merupakan suatu hal yang sangat penting dalam kehidupan seseorang baik dalam keluarga, masyarakat, bangsa bahkan membantu dalam perkembangan dunia. Seorang harus berwawasan luas atau berilmu pengetahuan, sehingga mereka pantas mencapai ketinggian dan keutuhan. 
Peranan Manajemen Sumber Daya Manusia (MSDM) diakui sangat menentukan bagi terwujudnya tujuan dari lembaga, tetapi untuk memimpin unsur manusia ini sangat sulit dan rumit. Pada Pasal 69 ayat 1 Undang-Undang Republik Indonesia Nomor 12 Tahun 2012 menyatakan bahwa ketenagaan perguruan tinggi terdiri dari dosen dan tenaga kependidikan. Terdapat 2 (dua) unsur SDM dalam perguruan tinggi yaitu Dosen dan tenaga administrasi (pegawai) dalam rangka mewujudkan tujuan Nasional pendidikan di Indonesia.

Pegawai sebagai pelaksana administrasi pada perguruan tinggi memiliki peran yang cukup strategis dalam rangka memberikan pelayanan administrasi baik kepada pihak internal (dosen dan mahasiswa) maupun kepada pihak eksternal (alumni, orang tua dan lembaga lain terkait) sebagai masyarakat dalam suatu perguruan tinggi. Keberhasilan pelayanan dibidang administrasi sangat ditentukan oleh kinerja yang tinggi dari seluruh pegawai, dimana kinerja yang tinggi diidentifikasi melalui kepuasan pengguna jasa, dalam hal ini adalah mahasiswa dan dosen.

Oleh karena itu, peningkatan kinerja sumber daya manusia (SDM) merupakan hal yang sangat penting di dalam usaha memperbaiki pelayanan kepada masyarakat, sehingga perlu diupayakan secara terus menerus dan berkesinambungan dalam menghadapi tuntunan masyarakat. Kualitas sumber daya manusia mempunyai peranan penting dalam meningkatkan pelayanan yang berkualitas, pegawai harus memiliki strategis yakni mempersiapkan diri untuk menjadi pelayan bagi seluruh masyarakat. Namun pelayanan yang berkualitas yang dapat memuaskan masyarakat terlayani masih dihadapkan pada masalah sampai saat ini belum dapat diatasi sepenuhnya. Permasalahan tersebut adalah masih rendahnya tingkat kualitas dan kuantitas pegawai yang dapat memaksimalkan kinerjanya untuk masyarakat.

Oleh karena itu, untuk memacu motivasi pegawai harus dilakukan dengan cara mendorong pencapaian kinerja yang baik. Motivasi merupakan proses pemberian motif (penggerak) bekerja kepada para pegawai sehingga mereka mau bekerja demi tercapainya tujuan lembaga secara efektif dan efisien. Pemberian motif kerja ini terdapat dalam teori hirarki kebutuhan Maslow yang meliputi kebutuhan fisiologis, kebutuhan keamanan, kebutuhan sosial, kebutuhan penghargaan dan kebutuhan aktualisasi diri. Dengan terpenuhinya semua kebutuhan atau keinginan dan harapan maka pegawai akan mendapatkan kepuasan, dan pegawai yang tingkat kepuasannya tinggi maka secara otomatis kinerjanya akan meningkat.

Demikian halnya kinerja, tidaklah mungkin mencapai hasil yang maksimal apabila tidak ada motivasi, karena motivasi merupakan suatu kebutuhan di dalam usaha untuk mencapai tujuan lembaga. Begitu juga berbagai ragam kemampuan pegawai akan sangat berpengaruh terhadap kinerja mengingat 
pegawai merupakan titik sentral dalam melaksanakan tugas pokok dan fungsinya.

Lebih lanjut setelah peneliti melakukan studi pendahuluan kepada beberapa responden secara acak, tentang bagaimana layanan atau kualitas pelayanan yang dialami dan dirasakan selama menjadi mahasiswa, di antaranya; Armin Kasim: mengatakan selama menjadi mahasiswa di Fakultas Tarbiyah dan Keguruan UIN Alauddin Makassar, pernah merasa kurang nyaman terhadap sebagian kecil pegawai yang kurang disiplin waktu dalam menyelesaikan berkas yang sudah disetor. Andi Iswa: mengatakan selama menjadi mahasiswa di Fakultas Tarbiyah dan keguruan UIN Alauddin Makassar, pernah mengalami dan merasakan kalau layanan yang diberikan oleh pihak administrasi akademik Fakultas kurang memperhatikan kenyamanan mahasiswa, seperti lambatnya proses pengurusan persuratan, dan pernah juga berkas yang sudah disetor di bagian administrasi tercecer, serta tidak ada yang mau bertanggung jawab untuk menyeleseikan. Ratnawati: mengomentari sistem Fakultas Tarbiyah dan Keguruan UIN Alauddin Makassar terkait program pendidikanya, bahwa sebaiknya sebelum mengangkat pegawai sebagai pelayanan administrasi, sebaiknya diadakan penyeleksian secara ketat, karena pernah menemui sebagian kecil pegawai yang pelayanannya tidak baik dan membeda-bedakan antara mahasiswa yang satu dengan yang lain.

Oleh karena itu, setelah peneliti mengamati dan merasakan realitas yang ada bahwa betapa pentingnya penyelengaraan pendidikan dan pelayanan yang bermutu, maka hal inilah yang mendorong dan mendasari penulis mengadakan penelitian untuk mengetahui adanya "Hubungan antara motivasi kerja dengan kinerja pegawai di Fakultas Tarbiyah dan Keguruan Universitas Islam Negeri Alauddin Makassar".

Berdasarkan uraian latar belakang masalah di atas, yang menjadi pokok permasalahan adalah sebagai berikut:

1. Bagaimana motivasi kerja pegawai di Fakultas Tarbiyah dan KeguruanUIN Alauddin Makassar?

2. Bagaimana kinerja pegawai di Fakultas Tarbiyah dan Keguruan UIN Alauddin Makassar?

3. Adakah hubungan yang signifikan antara motivasi kerja dengan kinerja pegawai di Fakultas Tarbiyah dan Keguruan UIN Alauddin Makassar?

\section{TINJAUAN TEORITIS}

\section{Motivasi Kerja}

Istilah motivasi berasal dari bahasa latin yaitu moveree yang berarti bergerak atau menggerakkan. Motivasi diartikan juga sebagai suatu kekuatan sumber daya yang menggerakkan dan mengendalikan perilaku manusia. Motivasi sebagai upaya yang dapat memberikan dorongan kepada seseorang untuk mengambil 
suatu tindakan yang dikehendaki, sebagai motif dan daya gerak seseorang untuk berbuat, karena perilaku seseorang cenderung berorientasi pada tujuan dan didorong oleh keinginan untuk mencapai tujuan tertentu.

As'ad mengemukakan bahwa motivasi kerja dalam psikologi karya biasa disebut pendorong semangat kerja. Kuat dan lemahnya motivasi seseorang tenaga kerja ikut menentukan besar kecilnya prestasinya.

Dalam konteks pekerjaan, motivasi merupakan salah satu faktor penting dalam mendorong seorang pegawai untuk bekerja. Motivasi adalah kesediaan individu untuk mengeluarkan upaya yang tinggi untuk mencapai tujuan organisasi. Ada tiga elemen kunci dalam motivasi yaitu upaya, tujuan organisasi dan kebutuhan. Upaya merupakan ukuran intensitas, bila seseorang termotivasi, maka ia akan berupaya sekuat tenaga untuk mencapai tujuan, namun upaya yang tinggi akan menghasilkan kinerja yang tinggi (Stephen P.Robbins, 1996:127)

Berdasarkan penjelasan di atas, maka dapat dipahami bahwa dalam motivasi kerja diperlukan intensitas dan kualitas dari upaya tersebut serta pegawai yang dapat memfokuskan diri pada tujuan dari organisasi. Dimana kebutuhan merupakan kondisi internal yang menimbulkan dorongan yang tidak terpuaskan yang akan menimbulkan tegangan yang merangsang dorongan dari dalam diri individu sehingga dorongan tersebut dapat menimbulkan perilaku pencarian untuk menemukakan tujuan tertentu. Jika kebutuhan terpenuhi, maka akan terjadi tegangan. Pada dasarnya, pegawai yang termotivasi berada dalam kondisi tegang dan berupaya untuk mengurangi ketegangan tersebut dengan melakukan upaya meghilangkannya dengan cara rileks.

Adapun motivasi kerja adalah motivasi yang menimbulkan semangat atau dorongan bekerja, sehingga motivasi kerja disebut pendorong semangat kerja. Kuat dan lemahnya motivasi kerja seseorang ikut menentukan prestasi kerjanya.

Dalam memotivasi seseorang bukan sekedar mendorong atau bahkan memerintahkan seseorang melakukan kegiatan atau pekerjaan secara serius, melainkan sebuah seni yang melibatkan berbagai kemampuan dalam mengenali dan mengelola emosi diri sendiri dan orang lain. Paling tidak yang harus diketahui bahwa seseorang melakukan sesuatu karena dorongan oleh motivasinya sendiri sehingga dapat menjalankan tugas dan tanggung jawabnya dengan baik agar tercapainya suatu tujuan dari suatu lembaga.

\section{Jenis dan Teknik Motivasi Kerja Pegawai}

Motivasi dalam bekerja terdapat beberapa jenis sebagai berikut: Motivasi positif, maksudnya manajer memotivasi (merangsang) bawahan dengan memberikan hadiah kepada mereka yang berprestasi di atas prestasi standar. Dengan memotivasi positif, semangat kerja bawahan akan meningkat karena umumnya manusia senang menerima yang baik-baik saja. Motivasi negative, maksudnya manajer memotivasi bawahan dengan standar mereka akan mendapat hukuman. Dengan motivasi negatif ini semangat bekerja bawahan 
dalam jangka waktu pendek akan meningkat karena mereka takut dihukum, tetapi dalam jangka waktu yang panjang dapat berakibat kurang baik. Sikap, (attitude motivation atau self motivation), motivasi muncul dari dalam dirinya sendiri karena menunjukkan ketertarikan seseorang terhadap suatu obyek (Malayu S.P. Hasibuan, 2006: 146)

Terdapat beberapa teknik memberikan motivasi kepada pegawai agar bekerja dengan baik, di antaranya; Berpikir positif: Ketika mengkritik orang begitu terjadi ketidakberesan, tetapi kita lupa memberi dorongan posiif agar mereka terus maju. Jangan menkritik cara kerja orang lain kalau kita sendiri tidak mampu memberi contoh terlebih dahulu. Menciptakan perubahan yang kuat: Adanya keamanan yang kuat untuk mengubah situasi oleh diri sendiri. Mengubah perasaan tidak mampu menjadi mampu, tidak mau menjadi mau. Kata "saya juga bisa" dapat membantu meningkatkan motivasi berprestasi. Membangun harga diri: Banyak kelebihan kita sendiri dan orang lain yang tidak hargai padahal penghargaan merupakan salah satu bentuk teknik memotivasi. Kata "saya mengharapkan bantuan Anda" merupakan bentuk penghargaan yang paling murah. Berilah mereka kesempatan untuk bertanggung jawab, berilah wewenang serta kebebasan untuk berpendapat (Husaini Usman, 2010: 272).

\section{Kinerja Pegawai}

Kinerja berasal dari pengertian performance. Ada pula yang memberikan pengertian performance sebagai hasil kerja atau prestasi kerja (Wibowo, 2013: 7). Wibowo menyatakan kinerja merupakan suatu proses tentang bagaimana pekerjaan berlangsung untuk mencapai hasil kerja.

Gibson et. Al yang dikutip Supardi mendefinisikan teori kinerja terbagi menjadi tiga kelompok variabel yang mempengaruhi kerja dan kinerja, yaitu: variabel individu, variabel organisasi, variabel psikologis.

Selanjutnya setelah memerhatikan teori kinerja yang diuraikan tersebut, bahwa kinerja seseorang bisa dipengaruhi oleh individunya, organisasi, maupun psikologisnya. Namun, bisa jadi jika kedewasaan dan kematangan seseorang sudah mumpuni, mungkin saja pengaruh-pengaruh dari subvariabel di atas tidaklah terlalu merisaukan, karena bisa disikapi secara moderat.

\section{Indikator Kinerja Pegawai}

Indikator kinerja atau performance indicators dipakai untuk aktivitas yang hanya dapat ditetapkan secara lebih kualitatif atas dasar perilaku yang diamati. Indikator kinerja juga menganjurkan sudut pandang prospektif (harapan kedepan), daripada retrospektif melihat kebelakang. Hal ini menunjukan jalan pada aspek kinerja yang perlu diobservasi.

Terdapat tujuh indikator kinerja yang dikutip Wibowo dari Paul Harsey dalam Management of Oerganizational Behavior merumuskan, sebagai berikut: tujuan, standar, umpan balik, alat atau sarana, kompetensi, motif dan peluang (Supardi, 2014: 45) 


\section{Langkah-Langkah Peningkatan Kinerja Pegawai}

Dalam buku Eka Suhartini menyatakan bahwa untuk peningkatan kinerja, paling tidak terdapat tujuh langkah yang dapat dilakukan sebagai berikut; mengetahui adanya kekurangan dalam kinerja, mengenai kekurangan dan tingkat keseriusan, melakukan rencana tindakan tersebut dan melakukan avaluasi apakah masalah tersebut sudah teratasi atau belum serta mulai dari awal apabila perlu.

\section{METODOLOGI PENELITIAN}

Jenis penelitian yang dilakukan adalah kuantitatif dengan pendekatan assosiatif. Bentuk dari penelitian assosiatif sendiri juga terbagi menjadi simetris, kausal dan inetraktif/resiprocal/timbal balik.

Penelitian dilakukan pada pegawai/tenaga kependidikan di Fakultas Tarbiyah dan Keguruan UIN Alauddin Makassar, khususnya pegawai yang memiliki kemampuan, kreativitas, inovatif dan tanggungjawab.

Yang menjadi populasi dalam penelitian ini adalah seluruh pegawai di Fakultas Tarbiyah dan Keguruan Universitas Islam Alauddin Makassar yang dimana tenaga kependidikan/tenaga administrasinya berjumlah 43 orang (Staf jurusan dan akademik baik PNS/ CPNS maupun honorer). Teknik pengambilan sampel pada penelitian ini adalah total sampling. Setelah data terkumpul, maka selanjutnya dilakukan analisis data dengan statistic deskriptif dan imprensial.

\section{HASIL PENELITIAN DAN PEMBAHASAN}

\section{Motivasi Pegawai Fakultas Tarbiyah dan Keguruan UIN Alauddin}

Berdasarkan data skor motivasi kerja di Fakultas Tarbiyah dan Keguruan UIN Alauddin Makassar, skor terendah 95 dan skor tertinggi 130, dengan mean sebesar 109, standar deviasi sebesar 8. Hasil perhitungan statistik deskripsi dikorelasi menjadi skala 3.

Untuk mengetahui kategori motivasi kerja di Fakultas Tarbiyah dan Keguruan UIN Alauddin Makassar, dapat diketahui dengan mengkategorikan skor responden.

Berdasarkan hasil analisis deskriptif tersebut, dengan memperhatikan 43 pegawai sebagai sampel, 8 atau 19\% pegawai barada dalam kategori rendah, 29 atau $67 \%$ pegawai yang barada dalam kategori sedang, sedangkan 6 atau $14 \%$ berada dalam kategori tinggi. Maka hal tersebut menggambarkan bahwa motivasi kerja pegawai di Fakultas Tarbiyah dan Keguruan UIN Alauddin Makassar berada dalam kategori sedang yakni $67 \%$.

\section{Kinerja Pegawai di Fakultas Tarbiyah dan Keguruan}

Berdasarkan data skor kinerja pegawai di Fakultas Tarbiyah dan Keguruan UIN Alauddin Makassar, skor terendah 89 dan skor tertinggi 130, dengan mean sebesar 106, standar deviasi sebesar 8. Hasil perhitungan statistik deskripsi dikorelasi menjadi skala 3. 
Berdasarkan hasil analisis deskriptif tersebut, dengan memperhatikan 43 pegawai sebagai sampel, 9 atau 21\% pegawai barada dalam kategori rendah, 28 atau 65\% pegawai berada dalam kategori sedang, dan 6 atau 14\% pegawai yang barada dalam kategori tinggi. Hal tersebut menggambarkan bahwa kinerja pegawai di Fakultas Tarbiyah dan Keguruan UIN Alauddin Makassar berada dalam kategori sedang yakni $65 \%$.

\section{Hubungan antara Motivasi Kerja dengan Kinerja Pegawai di Fakultas Tarbiyah dan Keguruan}

Teknik korelasi ini digunakan untuk mencari hubungan dan membuktikan hipotesis hubungan dua variabel bila data kedua variabel berbentuk interval atau ratio. Berikut ini dikemukakan rumus yang paling sederhana yang dapat digunakan untuk menghitung koefisien korelasi.

Hasil analisis data hasil penelitian tentang hubungan antara motivasi kerja dengan kinerja pegawai di Fakultas tarbiyah dan Keguruan UIN Alauddin Makassar sebagaimana yang tertera dalam tabel skor rata-rata hasil penelitian di atas. Adapun hipotesis penelitian yang diujikan dalam penelitian ini adalah "ada hubungan yang signifikan antara motivasi kerja dengan kinerja pegawai di Fakultas Tarbiyah dan Keguruan UIN Alauddin Makassar".

Dari hasil perhitungan dan tabel di atas dapat diketahui bahwa terdapat hubungan sangat kuat sebesar 0,997 antara motivasi kerja dengan kinerja pegawai di Fakultas Tarbiyah dan Keguruan Universitas Islam Negeri Alauddin Makassar.

Berdasarkan hasil di atas, maka motivasi kerja memberi kontribusi 99\% kepada kinerja pegawai dan sisanya 1\% adalah faktor lain yang tidak sempat diteliti. Dengan demikian, dari tabel untuk taraf signifikan dengan $n=43$, dari tabel $r$ kritis Pearson dihasilkan nilai $=0,301$ dan ternyata 0,301 berada pada koefisien korelasi 0,997, maka disimpulkan hubungan antara motivasi kerja dengan kinerja pegawai di Fakultas Tarbiyah dan Keguruan UIN Alauddin Makassar adalah positif dan signifikan dengan kategori sangat kuat sebesar 99\% sedangkan $1 \%$ dipengaruhi oleh faktor atau kriteria lain yang tidak sempat diteliti oleh peneliti.

\section{DAFTAR PUSTAKA}

Akbar, Asman Ali. "Hubungan Antara Motivasi Dalam Memilih Jurusan IPA Dengan Prestasi Belajar Siswa Pada Mata Pelajaran Biologi Kelas XI SMA Negeri 1 Poleang Kabupaten Bombana", Skripsi ( Makassar : Fakultas Tarbiyah dan Keguruan, Universitas Negeri Alauddin Makassar, 2015), h. 73-74.

Arikunto, Suharsimi. Manajemen Penelitian. Cet.XII, Jakarta: Rineka Cipta, 2013. Arsyad, Azhar, dkk. Buku Daras, Pengantar Manajemen 2. Makassar: Alauddin University Press, 2006. 
Astrini, Resky. "Pengaruh Motivasi Instrinsik dan Motivasi Ekstrinsik terhadap Produktivitas Kerja Pegawai pada Kantor Pelayanan Kekayaan Negara dan Lelang Makasar". Skripsi (Fakultas Ekonomi Universitas Hasanuddin, 2012),h.41. https://core.ac.uk/download/pdf/25486961.pdf.

Aswar, Saifuddin. Penyusunan Skala Psikologi. Cet. II; Yogyakarta: Pustaka Pelajar, 2012.

Azwar, Saifuddin. Metode Penelitian. Yogyakarta: Pustaka Pelajar, 2007.

Basyir, Ahmad Azhar. Garis Besar Sistem Ekonomi Islam. Yogyakarta: BPFE, 1987. Daryanto, Tutik Rachmawati. Penilaian Kinerja Profesi Guru Dan Angka Kreditnya Cet. I; Yogyakarta: Gava Media, 2013.

Gozali, Nasehudin, Toto Syatori dan Nanang. Metode Penelitian Kuntitatif. Cet.l; Bandung: Pustaka Setia, 2012.

Handoko, H. Manajemen Sumber Daya Manusia dan Personalia. BPFE UGM; Yogyakarta: 2012.

Hasibuan, Malayu S.P. Manajemen Sumber Daya Manusia. Jakarta: Bumi Aksara, 2006.

Kadarisman, M. Manajemen Sumber Daya Manusia. Cet. I; Jakarta: PT Raja Grafindo Persada. 2012.

Robbins, Stephen P. Perilaku Organisasi: Konsep, Kontraversi, Aplikasi. Alih Bahasa Hadayana dan Sarwanto. Cet. II; Jakarta: Ghalia Indonesia, 1996.

Sari, Aida Rahmita, "Hubungan Motivasi Dan Disiplin Kerja Terhadap Kinerja Guru di SMK Muhammadiyah 2 Yogyakarta", Skripsi. Yogyakarta: Fakultas Ekonomi, Universitas Negeri Yogyakarta, 2013.

Sugiyono. Metode Penelitian Pendidikan; Pendekatan Kuantitatif, Kualitatif dan R \& D. Cet. Vl; Bandung: Alfabeta, 2008.

Suharti, Kinerja Pegawai Suatu Kajian dengan Pendekatan Analisis Beban Kerja. Cet. I; Makassar: Alauddin University Press, 2012.

Universitas Islam Negeri Alauddin Makassar. Pedoman Karya Tulis IImiah, Makalah, Skripsi, Tesis, Disertasi, dan Laporan Penelitian. Makassar; Alauddin Press, 2013.

Uno, Hamzah B. Teori Motivasi dan Pengukurannya. Jakarta: Bumi Aksara, 2008. Usman, Husaini. Manajemen Teori, Praktik, dan Riset Pendidikan. Edisi III.Cet. II; Jakarta: 2010.

Wenty, Cici Syafri. “Hubungan Motivasi Kerja dengan Kinerja Pegawai di Dinas Pendidikan Kabupaten Pesisir Selatan", Jurnal Administrasi Pendidikan, vol. 3 no. 2 (2015) h. 941. (Diakses 3 Maret 2017). Wibowo. Manajemen Kinerja. 
SUARGA DAN NURITA

Widoyoko, S. Eko Putro. Teknik Penyusunan Instrumen Penelitian. Cet, III; Yogyakarta: Pustaka Pelajar, 2014.

Wirawan, Evaluasi Kinerja Sumber Daya Manusia Teori, Aplikasi dan Penelitian. Jakarta: Salemba Empat, 2009.

Yusmiar, A. Manajemen Sumber Daya Manusia dalam Peningkatan Kinerja Pegawai.Cet. 1; Makassar: Alauddin University Press, 2014. 